\title{
Decontamination Interventions for the Reuse of Surgical Mask Personal Protective Equipment (PPE): A Protocol for an Updated Systematic Review
}

PRISMA-P (Preferred Reporting Items for Systematic review and Meta-Analysis Protocols) 2015 checklist (1)

\begin{tabular}{|c|c|c|c|}
\hline Section/Topic & $\begin{array}{c}\text { Item } \\
\text { No. }\end{array}$ & Checklist Item & Protocol Information \\
\hline \multicolumn{4}{|c|}{ Administrative Information } \\
\hline \multicolumn{4}{|l|}{ Title } \\
\hline Identification & 1a & $\begin{array}{l}\text { Identify the report as a } \\
\text { protocol of a systematic } \\
\text { review }\end{array}$ & $\begin{array}{l}\text { Decontamination Interventions for the Reuse of Surgical } \\
\text { Mask Personal Protective Equipment (PPE): A Protocol } \\
\text { for an Updated Systematic Review }\end{array}$ \\
\hline Update & $1 \mathrm{~b}$ & $\begin{array}{l}\text { If the protocol is for an update } \\
\text { of a previous systematic } \\
\text { review, identify as such }\end{array}$ & $\begin{array}{l}\text { This is an update of an original systematic review } \\
\text { published on July } 9,2020 \text { (2). }\end{array}$ \\
\hline Registration & 2 & $\begin{array}{l}\text { If registered, provide the name } \\
\text { of the registry (e.g., } \\
\text { PROSPERO) and registration } \\
\text { number in the abstract }\end{array}$ & $\begin{array}{l}\text { The systematic review protocol was registered with the } \\
\text { International Prospective Register of Systematic Reviews } \\
\text { (PROSPERO) on February 11, } 2021 \text { (registration number } \\
\text { pending). The protocol will be uploaded in pre-print to } \\
\text { Open Science Framework (OSF). }\end{array}$ \\
\hline \multicolumn{4}{|r|}{ 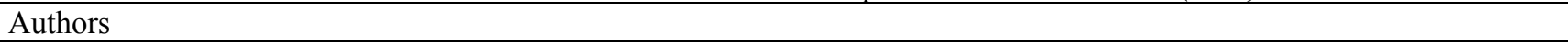 } \\
\hline \multirow[t]{12}{*}{ Contact } & $3 a$ & $\begin{array}{l}\text { Provide name, ORCID, } \\
\text { institutional affiliation, and e- } \\
\text { mail address of all protocol } \\
\text { authors; provide physical } \\
\text { mailing address of } \\
\text { corresponding author }\end{array}$ & $\begin{array}{l}\text { Corresponding author: David Zorko } \\
\text { (zorkodj@mcmaster.ca) } \\
\text { Department of Pediatrics, McMaster University } \\
\text { McMaster Children's Hospital, Room 3E20 } \\
\text { 1280 Main Street West Hamilton, Ontario, Canada } \\
\text { L8N 3Z5 } \\
\text { ORCID: 0000-0002-6971-8542 }\end{array}$ \\
\hline & & & $\begin{array}{l}\text { Karen Choong (choongk@mcmaster.ca) } \\
\text { McMaster University } \\
\text { ORCID: 0000-0002-4608-4508 }\end{array}$ \\
\hline & & & $\begin{array}{l}\text { James Dayre McNally (dmcnally@cheo.on.ca) } \\
\text { Children's Hospital of Eastern Ontario } \\
\text { ORCID: 0000-0001-8103-9967 }\end{array}$ \\
\hline & & & $\begin{array}{l}\text { Katie O’Hearn (kohearn@cheo.on.ca) } \\
\text { Children's Hospital of Eastern Ontario Research Institute } \\
\text { ORCID: 0000-0002-1149-2843 }\end{array}$ \\
\hline & & & Lindsey Sikora (lindsey.sikora@uottawa.ca) \\
\hline & & & University of Ottawa \\
\hline & & & ORCID: 0000-0002-9715-8634 \\
\hline & & & Tri Dinh (tri.dinh@medportal.ca) \\
\hline & & & McMaster University \\
\hline & & & ORCID: 0000-0002-6720-058X \\
\hline & & & Jess Gibson (jgibson@cheo.on.ca) \\
\hline & & & $\begin{array}{l}\text { Children's Hospital of Eastern Ontario Research Institute } \\
\text { ORCID: 0000-0001-5517-4540 }\end{array}$ \\
\hline Contributions & $3 \mathrm{~b}$ & $\begin{array}{l}\text { Describe contributions of } \\
\text { protocol authors and identify } \\
\text { the guarantor of the review }\end{array}$ & $\begin{array}{l}\text { Zorko } \\
\checkmark \text { Conceptualization } \checkmark \text { Methodology } \checkmark \text { Validation } \\
\checkmark \text { Investigation } \checkmark \text { Data curation } \checkmark \text { Writing 1st draft }\end{array}$ \\
\hline
\end{tabular}




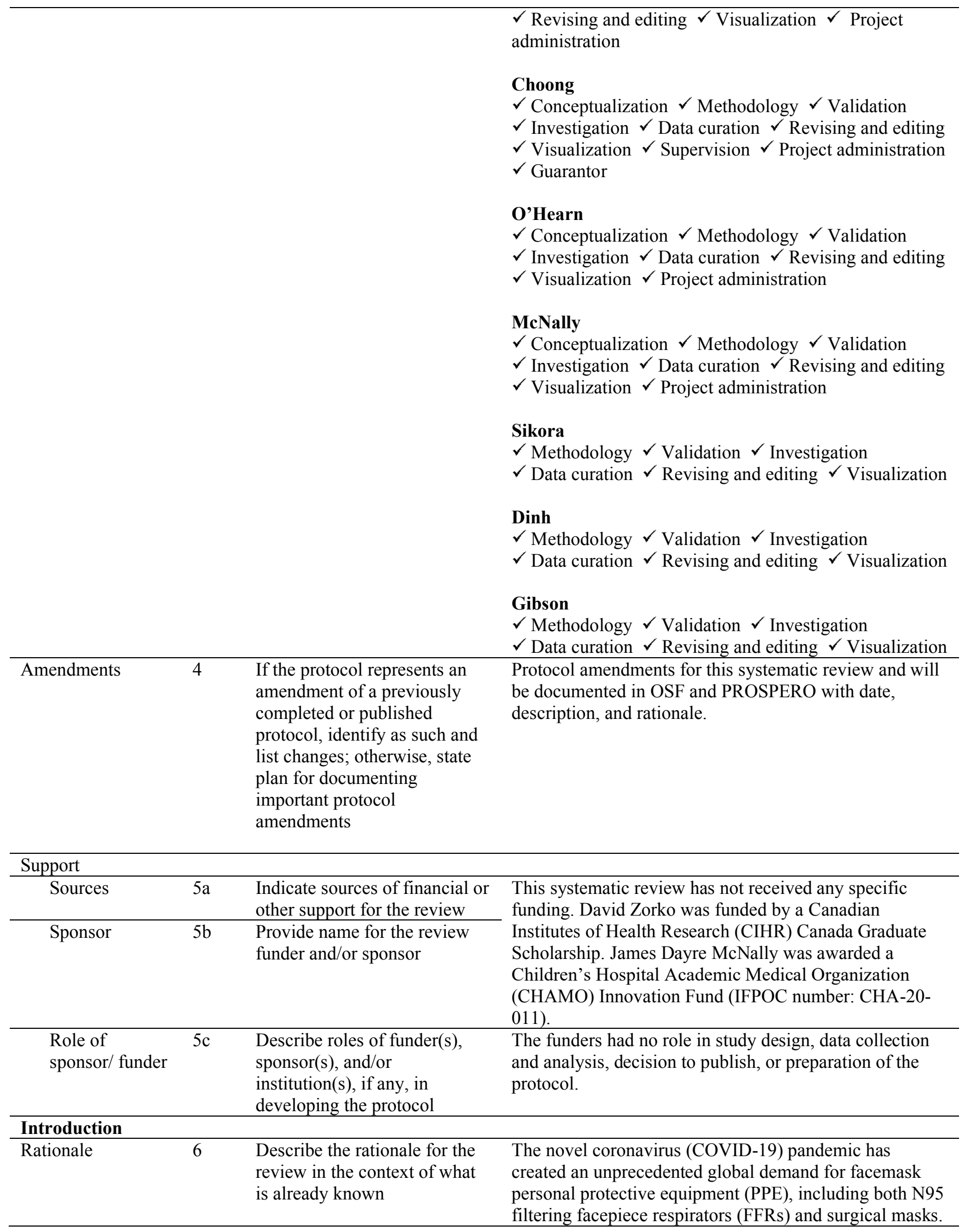


As a result, much attention came to mask decontamination as a potential crisis capacity strategy when faced with critical facemask PPE shortages (3). At the outset of the COVID-19 pandemic, little was known regarding the efficacy or safety of surgical mask decontamination interventions. Assumptions that decontamination methods effective in N95 FFRs can be extrapolated to surgical masks are challenged by evidence that decontamination interventions can variably impact mask performance amongst different mask types (2) and surgical masks perform differently than N95 FFRs with aerosol challenges $(4,5)$.

Therefore, our group conducted a systematic review to summarize the state of evidence for interventions facilitating the reuse of surgical masks (2). Conducted at the beginning of the COVID-19 pandemic, we identified a paucity of evidence evaluating interventions to decontaminate surgical masks for the purposes of reuse. Seven studies were included in the analysis with only one study evaluated decontamination interventions, specifically the effects of heat and chemical disinfectants on mask performance (5). Another six studies were identified that evaluated interventions applied prior to mask use to enhance their performance and/or antimicrobial properties (6-11). Both the scant body of evidence on decontamination interventions for surgical masks and the heterogeneity in the methods of included studies prevented us from making any actionable conclusions regarding surgical mask decontamination interventions.

The COVID-19 pandemic has placed surgical and medical facemask PPE in high demand. Their use spans a variety of healthcare settings (12-14) and many hospitals have implemented universal masking policies $(14,15)$. Furthermore, the emergence of COVID-19 variants with greater transmissibility and infectivity has led some countries to recommend or mandate widespread public use of 3-layer medical masks in lieu of homemade masks or face coverings (16). Since the publication of our original systematic review, COVID-19-related literature has evolved from $>2000$ citations in mid-March 2020 to $>80,000$ citations by the beginning of December 2020 . Coupled with the protracted course of the COVID-19 pandemic continuing to threaten facemask PPE supply and demand, an updated systematic review on decontamination interventions for surgical masks is needed to reflect critical new evidence in order to best inform clinicians, infection control experts, and public health administrators on how best to advise safe decontamination and reuse practices.

\begin{tabular}{llll}
\hline Objectives & 7 & $\begin{array}{l}\text { Provide an explicit statement } \\
\text { of the question(s) the review } \\
\text { will address with reference to } \\
\text { participants, interventions, }\end{array}$ & $\begin{array}{l}\text { This updated systematic review is a product of a larger } \\
\text { living scoping review seeking to identify all original } \\
\text { research on N95 FFR and surgical mask decontamination } \\
\text { and reuse, and create an open-access database of the }\end{array}$ \\
\hline
\end{tabular}


comparators, and outcomes

(PICO) existing literature (17). The objective of this systematic review is to update a previously conducted systematic review (2) and identify and synthesize new data from published studies evaluating interventions used to decontaminate or treat surgical mask PPE for the purposes of reuse.

\begin{tabular}{|c|c|c|}
\hline Methods & & \\
\hline Eligibility criteria & 8 & $\begin{array}{l}\text { Specify the study } \\
\text { characteristics (e.g., PICO, } \\
\text { study design, setting, time } \\
\text { frame) and report } \\
\text { characteristics (e.g., years } \\
\text { considered, language, } \\
\text { publication status) to be used } \\
\text { as criteria for eligibility for the } \\
\text { review }\end{array}$ \\
\hline
\end{tabular}

Population: Original publications evaluating medical or surgical facemask PPE (i.e., whole masks or pieces of whole masks) or their components (i.e., individual mask layers). For the purposes of this systematic review, the type of facemask PPE must be identified as a medical or surgical facemask approved for use in the hospital setting by healthcare providers. We will exclude studies that evaluated interventions isolated to N95 FFRs, or types of facemask PPE not routinely used in a hospital setting (e.g., non-medical masks, fabric masks [e.g., cotton, cloth], homemade facemasks).

Intervention: Any intervention used to decontaminate, sterilize or treat surgical face masks (i.e., an intervention applied after mask use), to enable the reuse of the mask as PPE.

Comparator: Any or none.

Outcome: Efficacy of the intervention, as measured by any one of the following:

1. Mask filtration performance (i.e., effect on droplet or particle penetration/filtration efficiency and airflow resistance)

2. Reduction in pathogen load (including viral, bacterial, fungal, and bacteriophage loads)

3. Mask appearance or physical degradation

4. Adverse effects as experienced by the wearer (e.g., skin irritation)

5. Feasibility of the intervention (e.g., time, cost, resource utilization)

6. Clinical infection prevention rates with use decontaminated masks (e.g., animal or human models)

Publication Characteristics: We will include English or French original publications examining any method of surgical mask PPE decontamination. We will also include systematic reviews of any method of medical and/or surgical mask PPE decontamination. Editorial reviews, narrative reviews, grey literature, clinical practice guidelines, patents and books will be excluded.

Information sources $9 \quad$ Describe all intended information sources (e.g., electronic databases, contact with study authors, trial registers, or other grey literature sources) with planned dates of coverage Eligible citations were identified through a living scoping review of N95 and surgical facemask PPE decontamination interventions (17). An updated search of electronic databases will be conducted from their dates of inception in March 2021. Consistent with the a priori methods of the living scoping review, the search strategy 
was reviewed and updated to reflect changes identified in the literature, terminology and indexing (17).

The following databases will be searched by the core investigator team and a health research librarian (LS, KO): Medline and Medline in Process via OVID, Embase Classic + Embase via OVID, Cochrane CENTRAL and Global Health via CAB Direct, and Senton Hall. The search strategy was developed in Medline, and then translated into the other databases, as appropriate (see Protocol Section 10). Language will be restricted to English or French, with no other publication restrictions. Reference lists of included studies will be examined for potential eligible citations that may have evaded the database search.

\begin{tabular}{|c|c|c|c|}
\hline Search strategy & 10 & $\begin{array}{l}\text { Present draft of search strategy } \\
\text { to be used for at least one } \\
\text { electronic database, including } \\
\text { planned limits, such that it } \\
\text { could be repeated }\end{array}$ & $\begin{array}{l}\text { Medline } \\
\text { 1. Respiratory Protective Devices/ } \\
\text { 2. Personal Protective Equipment/ } \\
\text { 3. (filtering adj3 (facepiece or face piece or facepieces } \\
\text { or face pieces)).tw,kf. } \\
\text { 4. (N95 or N 95).tw,kf. } \\
\text { 5. (ffr or ffrs).tw,kf. } \\
\text { 6. Masks/ } \\
\text { 7. (surgical mask* or medical mask* or cough mask* } \\
\text { or face mask* or (mask* and (personal or ppe or } \\
\text { gown* or glove*))).tw,kf. } \\
\text { 8. or/1-7 } \\
\text { 9. Decontamination/ } \\
\text { 10. exp Sterilization/ } \\
\text { 11. Equipment Reuse/ } \\
\text { 12. (decontamin* or steriliz* or deactivat* or } \\
\text { inactivat*).tw,kf. } \\
\text { 13. ((product or equipment or mask*) adj2 (reuse or } \\
\text { recycl* or reusabilit* or reprocess*)).tw,kf. } \\
\text { 14. Ultraviolet Rays/ } \\
\text { 15. ((ultraviolet or ultra violet or UV or actinic) adj3 } \\
\text { (ray or rays or radiation or irradiation or } \\
\text { decontaminat* or light)).tw,kf. } \\
\text { 16. UVGI.tw,kf. } \\
\text { 17. Microwaves/ } \\
\text { 18. (microwav* or micro wav*).tw,kf. } \\
\text { 19. ((ehf or extremely high frequenc*) adj2 (wave or } \\
\text { waves)).tw,kf. } \\
\text { 20. ((ultrahigh or ultra high) adj2 (wave or } \\
\text { waves)).tw,kf. } \\
\text { 24. Hydrogen Peroxide/ } \\
\text { 25. (bleach* or clorox or antiformin or oxygenated } \\
\text { 21. Steam/ or Hot Temperature/ } \\
\text { 22. (Heat or heated or heating or moist or steam or } \\
\text { oven or pasteuri* or autoclave).tw,kf. not (Body } \\
\text { Temperature/ or Body Temperature Regulation/ or } \\
\text { exp Heat Stress Disorders/) } \\
\text { 23. Sodium Hypochlorite/ or Disinfectants/ or Sodium } \\
\text { Chloride/ }\end{array}$ \\
\hline
\end{tabular}


26. sodium hypochlorite.tw,kf.

27. hydrogen peroxide.tw,kf.

28. Ethanol/

29. 2-Propanol/

30. Ethylene Oxide/

31. (ethanol* or isopropanol or iso-propanol or 2propanol or isopropyl alcohol or ethylene oxid* or oxirane or rubbing alcohol*).tw,kf.

32. disinfect*.tw,kf.

33. Nanotechnology/

34. exp Nanoparticles/ch [Chemistry]

35. (nanotechnolog* or nanostructur*).tw,kf.

36. Ozone/

37. Gamma rays/

38. ozone.tw,kf.

39. (gamma adj2 (ray* or radiation*)).tw,kf.

40. (nuclear adj2 (x-ray*).tw,kf.

41. exp Detergents/

42. detergent*.tw,kf.

43. (cleansing adj2 agent*).tw,kf.

44. or $/ 9-43$

45. 8 and 44

46. limit 45 to (english or french)

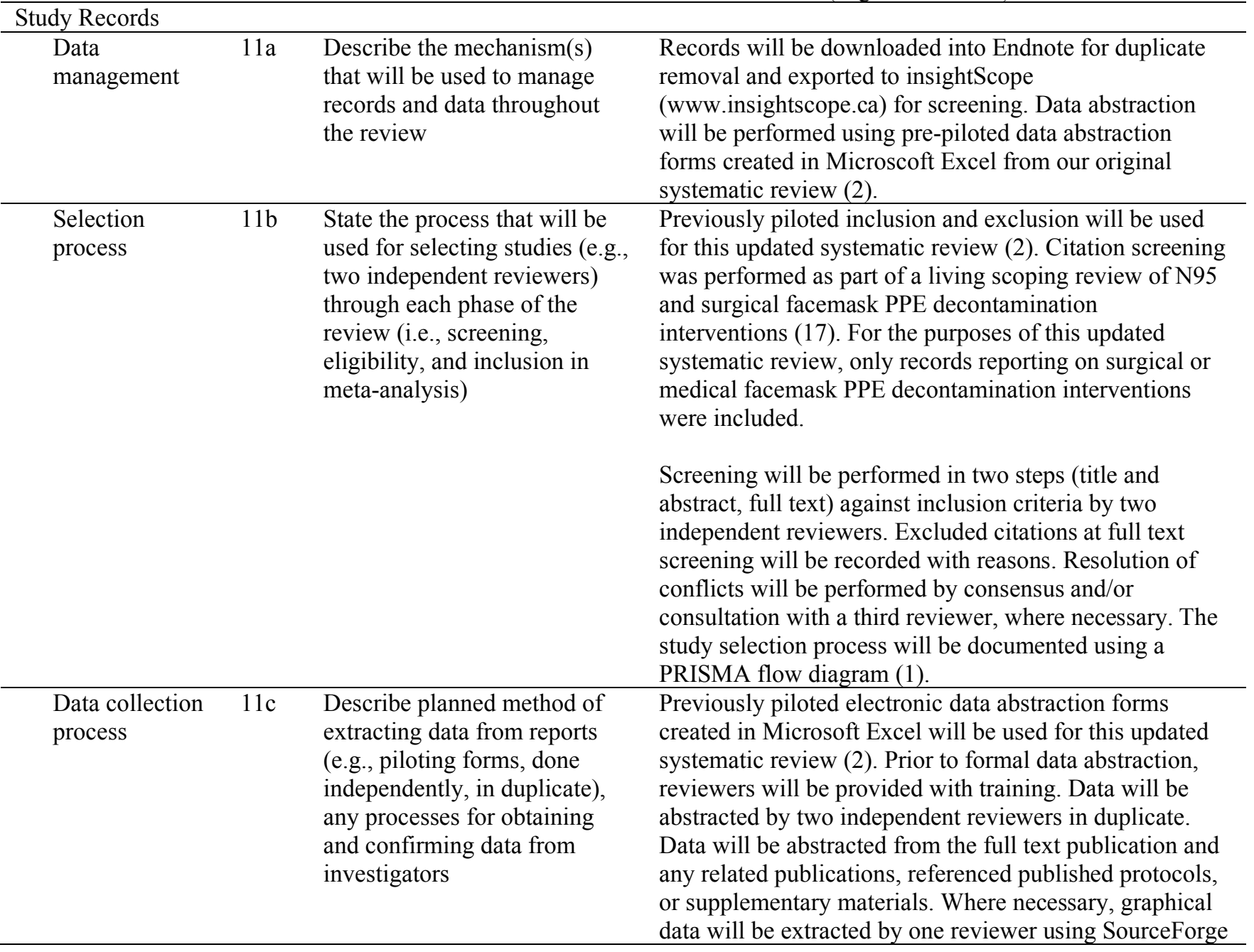


Plot Digitizer (http://plotdigitizer.sourceforge.net) and checked by the second reviewer for accuracy. Resolution of conflicts will be performed by consensus and/or consultation with a third reviewer, where necessary. In the event of missing or unclear data, a maximum of three attempts will be made to contact study authors for clarification.

\begin{tabular}{|c|c|c|c|}
\hline Data items & 12 & $\begin{array}{l}\text { List and define all variables } \\
\text { for which data will be sought } \\
\text { (e.g., PICO items, funding } \\
\text { sources), any pre-planned data } \\
\text { assumptions and } \\
\text { simplifications }\end{array}$ & 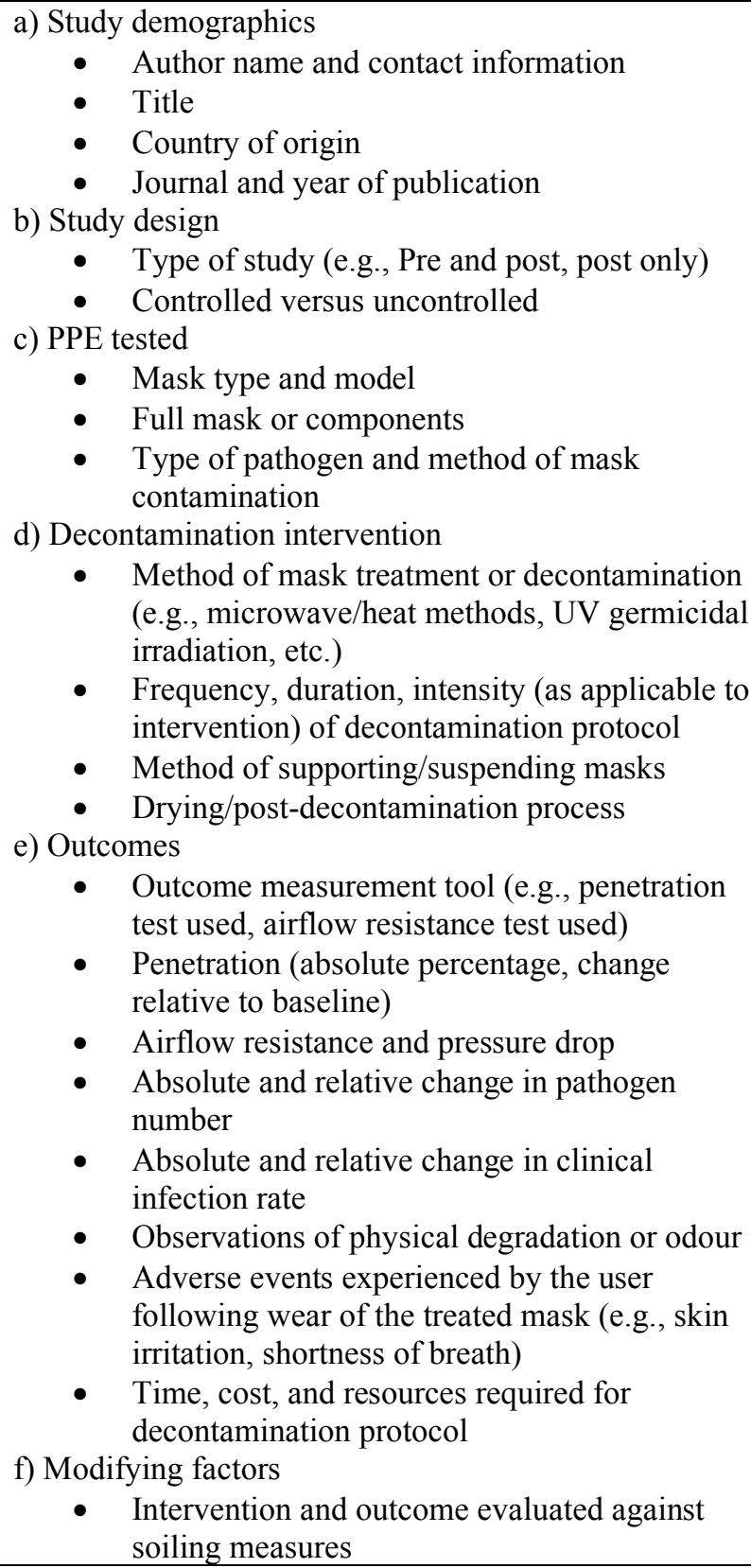 \\
\hline $\begin{array}{l}\text { Outcomes and } \\
\text { prioritization }\end{array}$ & 13 & $\begin{array}{l}\text { List and define all outcomes } \\
\text { for which data will be sought, } \\
\text { including prioritization of } \\
\text { main and additional outcomes, } \\
\text { with rationale }\end{array}$ & $\begin{array}{l}\text { The major outcomes for which data will be sought are: } \\
\text { 1. Filtration efficiency (FE; absolute values and } \\
\text { change pre- and post-use and intervention). } \\
\text { Study results reporting percentage particle } \\
\text { penetration were converted to FE units (i.e., } \\
\text { FE } \%=100 \text { - particle penetration) for } \\
\text { comparability (18). }\end{array}$ \\
\hline
\end{tabular}


2. Airflow resistance (absolute values and change pre- and post-use and intervention)

3. Pathogen load on the mask surface (absolute and relative change, when comparator group was included). Reduction in pathogen load will be reported as a $\log 10$ reduction factor from a time zero post inoculation to a subsequently measured time-point, in addition to absolute value or change. If $\log 10$ reductions are not reported by the study, we will calculate them using the study data provided (e.g., colony counts), where possible. A $\log 10$ reduction factor $\geq 3$ will be used as a reference indicating good germicidal effect (19).

The minor outcomes for which data will be sought are:

4. Changes in physical appearance, as defined by the study investigators (i.e., mask appearance or physical degradation, strap/ear-loop damage)

5. Adverse effects experienced by the wearer, as defined by the study investigators (e.g., skin irritation)

6. Feasibility, as defined by the study investigators (e.g., outcomes related to time, cost, and resource utilization for the intervention)

7. In-vivo infection rates following use of decontaminated masks (absolute and relative change, when comparator group was included)

\begin{tabular}{lll}
\hline Risk of bias in & 14 & $\begin{array}{l}\text { Describe anticipated methods } \\
\text { individual studies }\end{array}$ \\
& for assessing risk of bias of \\
& individual studies, including \\
& whether this will be done at \\
& the outcome or study level, or \\
& both; state how this \\
& information will be used in \\
& data synthesis
\end{tabular}

Given the absence of standard tools with which to assess risk of bias in this body of literature, risk of bias will be assessed using a systematic tool used in previous systematic reviews evaluating facemask PPE decontamination interventions $(2,20-22)$. Risk of bias will be assessed by two reviewers independently and in duplicate at the study level by outcome in the following domains: study design, methodological consistency, population heterogeneity, sampling bias, outcome evaluation, and selective reporting (Appendix A). Resolution of conflicts will be performed by consensus and/or consultation with a third reviewer, where necessary. If insufficient detail is provided to confidently assess risk of bias, a maximum of three attempts will be made to contact study authors for clarification. The impact of risk of bias on the summarized evidence will be addressed in the discussion section of the manuscript.

\begin{tabular}{lcl}
\hline Data synthesis & $15 \mathrm{a}$ & $\begin{array}{l}\text { Describe criteria under which } \\
\text { study data will be } \\
\text { quantitatively synthesized }\end{array}$
\end{tabular}
The following data will be synthesized quantitatively, stratified by decontamination intervention, provided that sufficient evidence exists:

1. FE and airflow resistance outcomes: Data will need to be available from at least three independent studies using approved testing methods to consider quantitative synthesis. Where results were presented for multiple experimental conditions, the summary of results conducted at the harshest testing conditions 
were reported, to allow a conservative

interpretation of the outcomes evaluated (18).

2. Germicidal outcome: Significant heterogeneity is expected in methodology related to pathogen type (e.g., virus versus bacteria) and method of evaluation of decontamination (e.g., culture versus PCR). We will quantitatively synthesize this outcome if similar data is provided from three studies using concordant pathogen and testing.

3. Mask degradation (fibre or other mask components)/physical appearance: It is expected that studies will subjectively evaluate this outcome, and thus significant heterogeneity is expected in the evaluation of physical characteristics. We will quantitatively synthesize this outcome if similar data is provided from three studies using approved, objective testing methods to consider quantitative synthesis.

4. User adverse event rate: Significant heterogeneity is expected in the methodology related to method of decontamination and adverse event measured. We will quantitatively synthesize this outcome if similar data is provided from three studies evaluating a concordant decontamination method and evaluating the same adverse event.

5. Feasibility: Significant heterogeneity is expected in the methodology related to method of decontamination and choice and measurement of a feasibility outcome. We will quantitatively synthesize this outcome if similar data is provided from three studies evaluating a concordant decontamination method and the same feasibility outcome.

6. Clinical infection prevention rate: Significant heterogeneity is expected in methodology related to pathogen type (e.g., virus versus bacteria) and method of evaluation of decontamination (e.g., culture versus PCR). We will quantitatively synthesize this outcome if similar data is provided from three studies using concordant pathogen and testing.

$15 \mathrm{~b}$ If data are appropriate for quantitative synthesis, describe planned summary measures, methods of handling data, and methods of combining data from studies, including any planned exploration of consistency (e.g., $I^{2}$, Kendall's tau)
For the particle penetration and airflow resistance outcomes of interest, the data is anticipated to be primarily presented as an absolute value. If presented as a percent change, and sufficient data is provided, we will calculate the absolute value.

For the germicidal outcomes of interest, heterogeneity is expected with respect to methods and outcomes related to contamination and decontamination. The data is anticipated to be reported as absolute and/or relative change, when comparator group was included. In order to account for differences in methods, pooled results will be summarized in terms of a $\log 10$ reduction factor. If $\log 10$ 
reductions are not reported by the study, we will calculate them using the study data provided (e.g., colony counts), where possible. For studies reporting a pathogen load "below minimum detectable limits," we will calculate a $\log 10$ reduction factor using half of the limit of detection, as previously described (23) and used in other studies $(20,24)$. Consistent with our previous approach, for studies that report a final pathogen load of "zero" and no limit of detection, it will be assumed that all pathogen was inactivated (20). Similarly, if studies report a pathogen load "below minimum detectable limits" and no limit of detection, it will be assumed that all pathogen was inactivated (20).

A random effects model will be used to present either the pooled absolute value pre-/post-decontamination intervention or relative change (from control or no intervention arm). The Mantel-Haenszel method will be used to estimate study weights. We will calculate pooled risk ratios for dichotomous outcomes and mean differences for continuous outcomes, with a corresponding $95 \% \mathrm{CI}$. A two-sided $\mathrm{p}$-value $<0.05$ will be considered significant.

The degree of statistical heterogeneity will be evaluated from forest plots, using chi-square tests $(\mathrm{p}<0.10$ representing significant heterogeneity) and the $\mathrm{I}^{2}$ statistic $\left(\mathrm{I}^{2}>50 \%\right.$ representing moderate to substantial heterogeneity).

\begin{tabular}{|c|c|c|}
\hline $15 \mathrm{c}$ & $\begin{array}{l}\text { Describe any proposed } \\
\text { additional analyses (e.g., } \\
\text { sensitivity or subgroup } \\
\text { analyses, meta-regression) }\end{array}$ & $\begin{array}{l}\text { Additional analyses are as follows: } \\
\text { 1. For the synthesis and presentation of } \\
\text { decontamination results we will perform a } \\
\text { separate analysis limiting to studies that evaluate } \\
\text { specific pathogen types (e.g., viruses, bacteria), } \\
\text { where possible. } \\
\text { 2. For the synthesis and presentation of mask } \\
\text { performance results (airflow resistance and FE) } \\
\text { we will perform separate analyses evaluating } \\
\text { specific mask types (by model and/or } \\
\text { performance standard [e.g., ASTM level], where } \\
\text { possible. } \\
\text { 3. For the synthesis and presentation of mask } \\
\text { performance and decontamination results, } \\
\text { separate analysis limited to studies that } \\
\text { evaluated used masks (i.e., those already worn in } \\
\text { the healthcare setting), where possible. Recent } \\
\text { data relating to decontamination of N95 FFRs } \\
\text { has demonstrated that used facemasks may } \\
\text { perform differently to decontamination } \\
\text { interventions than unused masks (25). } \\
\text { 4. If sufficient data permits (at least three studies) } \\
\text { we will describe and quantitatively synthesize } \\
\text { the data for low risk of bias studies. }\end{array}$ \\
\hline $15 d$ & $\begin{array}{l}\text { If quantitative synthesis is not } \\
\text { appropriate, describe the type } \\
\text { of summary planned }\end{array}$ & $\begin{array}{l}\text { If there is insufficient quantity or quality of data or the } \\
\text { methods are sufficiently heterogenous the study findings } \\
\text { will be presented descriptively in tables and text. }\end{array}$ \\
\hline
\end{tabular}




\begin{tabular}{lcll}
\hline Meta-bias(es) & 16 & $\begin{array}{l}\text { Specify any planned } \\
\text { assessment of meta-bias(es) } \\
\text { (e.g., publication bias across } \\
\text { studies, selective reporting } \\
\text { within studies) }\end{array}$ & $\begin{array}{l}\text { Based on the anticipated small size of the available } \\
\text { literature (approximately 10 studies per decontamination } \\
\text { intervention) and limited variability in study sample sizes } \\
\text { generally observed in laboratory studies, no statistical test } \\
\text { of publication bias are planned. }\end{array}$ \\
\hline $\begin{array}{l}\text { Confidence in } \\
\text { cumulative }\end{array}$ & 17 & $\begin{array}{l}\text { Describe how the strength of } \\
\text { the body of evidence will be } \\
\text { evidence }\end{array}$ & $\begin{array}{l}\text { The cumulative body of evidence regarding the reuse and } \\
\text { decontamination of surgical mask PPE will be evaluated } \\
\text { asing the following domains: 1) Study quality, 2) Risk of } \\
\text { bias, 3) Precision, 4) Consistency, and 5) Indirectness. } \\
\text { A final overall quality of evidence will be summarized in } \\
\text { a summary of findings table. }\end{array}$ \\
& & \\
\end{tabular}

\section{References:}

1. Moher D, Shamseer L, Clarke M, Ghersi D, Liberati A, Petticrew M, et al. Preferred reporting items for systematic review and meta-analysis protocols (PRISMA-P) 2015 statement. Syst Rev. 2015;4(1). doi: 10.1186/2046-4053-4-1

2. Zorko DJ, Gertsman S, O'Hearn K, Timmerman N, Ambu-Ali N, Dinh T, et al. Decontamination interventions for the reuse of surgical mask personal protective equipment: a systematic review. $J$ Hosp Infect. 2020;106(2):283-94. doi: 10.1016/j.jhin.2020.07.007

3. Centers for Disease Control and Prevention. Strategies for Optimizing the Supply of Facemasks 2020, https://www.cdc.gov/coronavirus/2019-ncov/hcp/ppe-strategy/face-masks.html [accessed February 11, 2021]

4. Bałazy A, Toivola M, Adhikari A, Sivasubramani SK, Reponen T, Grinshpun SA. Do N95 respirators provide 95\% protection level against airborne viruses, and how adequate are surgical masks? Am J Infect Control. 2006;34(2):5157. doi: 10.1016/j.ajic.2005.08.018

5. Lin T-H, Chen C-C, Huang S-H, Kuo C-W, Lai C-Y, Lin W-Y. Filter quality of electret masks in filtering 14.6-594 $\mathrm{nm}$ aerosol particles: Effects of five decontamination methods. PloS One. 2017;12(10). doi: 10.1371/journal.pone.0186217

6. Tseng C-C, Pan Z-M, Chang C-H. Application of a quaternary ammonium agent on surgical face masks before use for pre-decontamination of nosocomial infection-related bioaerosols. Aerosol Sci Tech. 2016;50(3):199-210. doi: $10.1080 / 02786826.2016 .1140895$

7. Shen H, Leonas KK. Study of Repellent Finish Of Filtration Ability Of Surgical Face Masks. International Nonwovens Journal. 2005(4):1558925005os-1551400403. doi: 10.1177/1558925005os-1400403

8. Quan F-S, Rubino I, Lee S-H, Koch B, Choi H-J. Universal and reusable virus deactivation system for respiratory protection. Sci Rep. 2017;7(1):1-10. doi: 10.1038/srep39956

9. Li Y, Wong T, Chung, Guo YP, Hu JY, Guan YT, et al. In vivo protective performance of N95 respirator and surgical facemask. Am J Ind Med. 2006;49(12):1056-1065. doi: 10.1002/ajim.20395

10. Li Y, Leung P, Yao L, Song Q, Newton E. Antimicrobial effect of surgical masks coated with nanoparticles. J Hosp Infect. 2006;62(1):58-63. doi: 10.1016/j.jhin.2005.04.015

11. Demir B, Cerkez I, Worley S, Broughton R, Huang T-S. N-halamine-modified antimicrobial polypropylene nonwoven fabrics for use against airborne bacteria. ACS Appl Mater Interfaces. 2015;7(3):1752-1757. doi: $10.1021 / \mathrm{am} 507329 \mathrm{~m}$

12. MacIntyre CR, Chughtai AA. Facemasks for the prevention of infection in healthcare and community settings. $B M J$. 2015;350:h694. doi: 10.1136/bmj.h694

13. World Health Organization. Rational use of personal protective equipment for coronavirus disease (COVID-19) and considerations during severe shortages: interim guidance, 6 April 2020. Geneva: World Health Organization; 2020.

14. World Health Organization. Advice on the use of masks in the context of COVID-19: interim guidance, 6 April 2020. Geneva: World Health Organization; 2020.

15. Klompas M, Morris CA, Sinclair J, Pearson M, Shenoy ES. Universal masking in hospitals in the Covid-19 era. $N$ Eng J Med. 2020. doi: 10.1056/NEJMp2006372

16. Mackintosh, Eliza. European countries mandate medical-grade masks over homemade cloth face coverings. CNN [newspaper on the Internet]. January 22, 2021 [accessed February 11, 2021]. Available at:https://www.cnn.com/2021/01/22/europe/europe-covid-medical-masks-intl/index.html

17. O'Hearn K, Agarwal A, Choong K, Gertsman S, Nama N, Sampson M, et al. Live Scoping Review of N95 and Surgical Facemask Decontamination and Reuse: A Scoping Review Protocol. OSF Preprints. 2020. doi: 10.31219/osf.io/rpc27

18. Rengasamy S, Shaffer R, Williams B, Smit S. A comparison of facemask and respirator filtration test methods. $J$ Occup Environ Hyg. 2017;14(2):92-103. doi: 10.1080/15459624.2016.1225157 
19. Fisher EM, Noti JD, Lindsley WG, Blachere FM, Shaffer RE. Validation and application of models to predict facemask influenza contamination in healthcare settings. Risk Anal. 2014;34(8):1423-1434. doi: 10.1111/risa.12185

20. Gertsman S, Agarwal A, O'Hearn K, Webster R, Tsampalieros A, Barrowman N, et al. Microwave- and heat-based decontamination of N95 filtering facepiece respirators: a systematic review. $J$ Hosp Infect. 2020;106(3):536-553. doi: $10.1016 /$ j.jhin.2020.08.016

21. O'Hearn K, Gertsman S, Sampson M, Webster R, Tsampalieros A, Ng R, et al. Decontaminating N95 and SN95 masks with ultraviolet germicidal irradiation does not impair mask efficacy and safety. $J$ Hosp Infect. 2020;106(1):163-75. doi: 10.1016/j.jhin.2020.07.014

22. O'Hearn K, Gertsman S, Webster R, Tsampalieros A, Ng R, Gibson J, et al. Efficacy and safety of disinfectants for decontamination of N95 and SN95 filtering facepiece respirators: a systematic review. $J$ Hosp Infect. 2020;106(3):504-521. doi: 10.1016/j.jhin.2020.08.005.

23. Singh A, Nocerino J. Robust estimation of mean and variance using environmental data sets with below detection limit observations. Chemometrics and Intelligent Laboratory Systems. 2002;60(1-2):69-86. doi: 10.1016/S01697439(01)00186-1.

24. Heimbuch BK, Wallace WH, Kinney K, Lumley AE, Wu C-Y, Woo M-H, et al. A pandemic influenza preparedness study: Use of energetic methods to decontaminate filtering facepiece respirators contaminated with H1N1 aerosols and droplets. Am J Infect Control. 2011;39(1):e1-e9. doi: 10.1016/j.ajic.2010.07.004

25. Czubryt MP, Stecy T, Popke E, Aitken R, Jabusch K, Pound R, et al. N95 mask reuse in a major urban hospital: COVID-19 response process and procedure. $J$ Hosp Infect. 2020;106(2):277-82. doi: 10.1016/j.jhin.2020.07.035 
Appendix A. Risk of bias assessment criteria and scoring

\begin{tabular}{|c|c|c|c|c|c|}
\hline Domain & Study Outcome & Low Risk (0 points) & Moderate Risk (1 point) & High Risk (2 points) & Unclear $^{\mathrm{a}}$ \\
\hline Study Design & All & Controlled study or pre-post design & $\begin{array}{l}\text { Partially controlled, quasi-experimental, } \\
\text { or case-control design }\end{array}$ & $\begin{array}{l}\text { Uncontrolled and no pre-post } \\
\text { design }\end{array}$ & $\begin{array}{l}\text { Insufficient } \\
\text { information }\end{array}$ \\
\hline \multirow{6}{*}{$\begin{array}{l}\text { Methodology } \\
\text { Consistency }\end{array}$} & $\begin{array}{l}\text { Filtration } \\
\text { efficiency }\end{array}$ & $\begin{array}{l}\text { Particle diameter, size distribution, charge, } \\
\text { and airflow rate are consistent across arms }\end{array}$ & Some of the stated criteria not reported & None of the stated criteria reported & $\begin{array}{l}\text { Insufficient } \\
\text { information }\end{array}$ \\
\hline & $\begin{array}{l}\text { Airflow } \\
\text { Resistance }\end{array}$ & Airflow rate is consistent across arms & Some of the stated criteria not reported & None of the stated criteria reported & $\begin{array}{l}\text { Insufficient } \\
\text { information }\end{array}$ \\
\hline & Germicidal Effect & $\begin{array}{l}\text { Detailed description of pathogen inoculation } \\
\text { procedure (including inoculation medium and } \\
\text { transmission mode) and assay procedure } \\
\text { (including times/temperatures where } \\
\text { applicable); procedures consistent across arms } \\
\text { unless they are experimental variables }\end{array}$ & Some of the stated criteria not reported & None of the stated criteria reported & $\begin{array}{l}\text { Insufficient } \\
\text { information }\end{array}$ \\
\hline & $\begin{array}{l}\text { Infection } \\
\text { Prevention }\end{array}$ & $\begin{array}{l}\text { Detailed description of infection apparatus; } \\
\text { ambient temperature and aerosol pressure are } \\
\text { consistent across arms }\end{array}$ & Some of the stated criteria not reported & None of the stated criteria reported & $\begin{array}{l}\text { Insufficient } \\
\text { information }\end{array}$ \\
\hline & $\begin{array}{c}\text { Physical } \\
\text { Characteristics }\end{array}$ & $\begin{array}{l}\text { Description of how masks were evaluated, and } \\
\text { all arms evaluated the same way }\end{array}$ & Some of the stated criteria not reported & None of the stated criteria reported & $\begin{array}{l}\text { Insufficient } \\
\text { information }\end{array}$ \\
\hline & Adverse Effects & $\begin{array}{l}\text { Description of how masks were evaluated, and } \\
\text { all arms evaluated the same way }\end{array}$ & Some of the stated criteria not reported & None of the stated criteria reported & $\begin{array}{l}\text { Insufficient } \\
\text { information }\end{array}$ \\
\hline \multirow{2}{*}{$\begin{array}{l}\text { Population } \\
\text { Heterogeneity }\end{array}$} & All & $\begin{array}{l}\text { Masks or mask components derived from the } \\
\text { same batch/lot, and each different model } \\
\text { analyzed separately }\end{array}$ & $\begin{array}{l}\text { Some of the stated criteria not reported } \\
\text { (e.g. mask models analyzed separately } \\
\text { but lots not specified) }\end{array}$ & None of the stated criteria reported & $\begin{array}{l}\text { Insufficient } \\
\text { information }\end{array}$ \\
\hline & $\begin{array}{l}\text { Adverse Effects }{ }^{\mathrm{b}} \\
\text { Infection } \\
\text { Prevention }^{\mathrm{b}}\end{array}$ & $\begin{array}{l}\text { Homogenous subjects (Animal—same age, } \\
\text { breed, and sex; Humans—same age and sex } \\
\text { distribution) }\end{array}$ & Some of the stated criteria not reported & None of the stated criteria reported & $\begin{array}{l}\text { Insufficient } \\
\text { information }\end{array}$ \\
\hline $\begin{array}{l}\text { Sampling } \\
\text { Bias }\end{array}$ & All & $\begin{array}{l}\text { No indication that any masks were excluded } \\
\text { from tests, or clear indication of exclusion } \\
\text { with analyses accounting for the missing } \\
\text { information }\end{array}$ & $\begin{array}{l}\text { Data missing for some samples and not } \\
\text { accounted for in analysis or conclusions }\end{array}$ & $\begin{array}{l}\text { Samples replaced by new masks } \\
\text { (e.g. if untestable due to } \\
\text { degradation) and exclusion of } \\
\text { original samples is not accounted } \\
\text { for in analysis or conclusions }\end{array}$ & $\begin{array}{l}\text { Insufficient } \\
\text { information }\end{array}$ \\
\hline $\begin{array}{c}\text { Outcome } \\
\text { Evaluation }\end{array}$ & All & $\begin{array}{l}\text { Results determined by blinded evaluators or a } \\
\text { machine (i.e. objective) }\end{array}$ & $\begin{array}{l}\text { Partially-machine measured and/or } \\
\text { partially-blinded evaluation }\end{array}$ & $\begin{array}{l}\text { Unblinded evaluator or other } \\
\text { subjective manner }\end{array}$ & $\begin{array}{l}\text { Insufficient } \\
\text { information }\end{array}$ \\
\hline $\begin{array}{l}\text { Selective } \\
\text { Reporting }\end{array}$ & All & $\begin{array}{l}\text { Results for all specified objectives and tests } \\
\text { are reported, and/or missing data is clearly } \\
\text { accounted for in analysis; all reported results } \\
\text { were mentioned in the methods/objectives }\end{array}$ & $\begin{array}{l}\text { Results of all objectives/tests are } \\
\text { included or accounted for but results that } \\
\text { were not specified in the } \\
\text { methods/objective are also reported }\end{array}$ & $\begin{array}{l}\text { Results for some objectives/tests } \\
\text { are missing and not accounted for }\end{array}$ & $\begin{array}{l}\text { Insufficient } \\
\text { information }\end{array}$ \\
\hline \multicolumn{2}{|c|}{$\begin{array}{l}\text { Overall Study Risk of Bias } \\
\text { (Sum Score) }\end{array}$} & $\begin{array}{l}\text { Low Risk of Bias } \\
\text { (sum score 0-1) }\end{array}$ & $\begin{array}{l}\text { Moderate Risk of Bias } \\
\text { (sum score 2-6) }\end{array}$ & $\begin{array}{l}\text { High Risk of Bias } \\
\text { (sum score 7-12) }\end{array}$ & \\
\hline
\end{tabular}

${ }^{a}$ For studies with unclear risk of bias in a domain, a range of overall risk of bias was provided assuming low and high risk of bias scores in these domains, respectively.

${ }^{\mathrm{b}}$ Two risk of bias scores were assessed for the population heterogeneity domain —one risk of bias score for the mask population and one for the population in which

infection/adverse effects were assessed. The average domain score was used in the calculation of overall risk of bias. 